\title{
SOCIALINIO DARBUOTOJO PATIRIAMOS PROBLEMOS DIRBANT SU SOCIALINĖS RIZIKOS ŠEIMOMIS
}

\author{
Eglẻ Stasiūnaitienė, Simona Mažeikaitė \\ Kauno kolegijos Medicinos fakultetas
}

Raktažodžiai: socialinis darbuotojas, problema, socialinès rizikos šeima.

\begin{abstract}
Santrauka
Socialinis darbas su socialinès rizikos šeimomis yra ịvairiapusiškai sudètingas. Socialinis darbuotojas, stengdamasis padèti socialinès rizikos šeimoms ịveikti iškilusias problemas, dažnai pats susiduria su situacijomis, kurios kelia grèsmę ne tik psichologiniam, bet ir fiziniam jo saugumui. Tyrimo rezultatu analizè atskleidè, kad socialiniai darbuotojai dažniausiai patiria problemų bendraudami su socialinès rizikos šeimomis, teikdami socialines paslaugas joms bei lankydamiesi šių šeimų namuose. Šių problemų socialiniai darbuotojai patiria dèl socialinès rizikos šeimų narių priešiško nusistatymo prieš jų teikiamą profesionalią pagalbą, bendravimo vengimo, motyvacijos stokos ir pasyvumo keistis. Atlikus tyrimą paaiškèjo, kad didžioji dalis socialinių darbuotojų jaučia nerimą vykdami ị socialinès rizikos šeimų namus dẻl kylančios grèsmès jų fiziniam ir psichologiniam saugumui. Tyrime dalyvavusieji socialiniai darbuotojai pažymèjo, kad jiems trūksta glaudesnio bendradarbiavimo su kitomis institucijomis, socialiniais partneriais.
\end{abstract}

\section{Ivadas}

Intensyvus šiuolaikinio gyvenimo ritmas ir aplinka sąlygoja aplinkybes, jog šeimos, nesugebančios prisitaikyti prie sparčios gyvenimo kaitos, patiria sunkiai savarankiškai išsprendžiamas problemas, kurios sąlygoja šeimos tapimą socialinès rizikos šeima. Socialinès rizikos šeima apibūdinama kaip šeima, kurioje narių bendradarbiavimas ir emocinis bendravimas yra sutrikę ir kurios neigiama aplinka neskatina sveiko ir produktyvaus asmenybès augimo ir vystymosi. Tokios šeimos nesugeba tenkinti vaiko emocinių ir fizinių reikmių, be to, bendravimo būdas tokiose šeimose žymiai apriboja vaiko galimybes išreikšti po- reikius ir jausmus. Vaikai, augantys tokiose šeimose, labai žemai save vertina, nesitiki, kad jų poreikiai yra svarbūs ir gali būti patenkinti, neturi tinkamų socialinių igūdžių [1]. Socialinès rizikos šeimų formavimosi priežastys yra labai įvairios, tačiau pagrindinès yra socialinè atskirtis, skurdas, nedarbas ir alkoholio vartojimas. Šios priežastys yra glaudžiai susijusios ir dažnai nulemia viena kitą. Amerikiečių tyrejjų R. Repetti, S. Taylor ir T. Seeman teigimu, socialinès rizikos šeimų atsiradimą lemia ne tik socialiniai, bet ir genetiniai faktoriai. Vaikas, užaugęs socialinès rizikos šeimoje, vẻliau dažniausiai pats sukuria šeimą, kuri anksčiau ar vèliau pakliūna ị socialinès rizikos grupę. Nuolatinis stresas, smurtas, prievarta ir skurdas, vyraujantis socialinès rizikos šeimų aplinkoje, neigiamai veikia vaiko asmenybès formavimąsi [9].

Socialinès rizikos šeimoms reikalinga visapusiška socialinio darbuotojo ir kitų komandoje dirbančių specialistų pagalba. L. C. Johnson teigimu, socialinis darbas su socialinès rizikos šeimomis yra nukreiptas ị problemų sprendimą ir pokyčių siekimą [4]. Socialinis darbuotojas bendrauja su socialinès rizikos šeimomis, lankosi jų namuose, kartu su šeimų nariais sudaro socialinių problemų sprendimo darbo planą, teikia socialines paslaugas šeimoms bei bendradarbiauja su kitomis institucijomis ir socialiniais partneriais.

Socialinis darbas su socialinès rizikos šeimomis yra ivvairiapusiškai sudètingas, reikalaujantis didžiulès emocinès investicijos. Socialiniai darbuotojai dažnai susiduria su problemomis, kurios kelia grèsmę psichologiniam ir fiziniam jų saugumui. Dažnai socialinès rizikos šeimų nariai priešinasi socialinio darbuotojo intervencijai ic jų gyvenimą, neigia savo problemas, nesprendžia jų, vengia bendravimo, būna priešiškai nusiteikę. Socialiniai darbuotojai išreiškia nepasitenkinimą, kad jų profesinè veikla vis dar turi per žemą prestižą visuomenèje, jaučiasi nepakankamai įvertinami kitų profesijų atstovų, trūksta glaudesnio bendradarbiavimo holistiškai sprendžiant socialinès rizikos šeimų problemas.

Tyrimo tikslas - nustatyti socialinio darbuotojo, dir- 
bančio su socialinès rizikos šeimomis, patiriamas problemas.

\section{Tyrimo metodas ir objektas}

Atlikti 4 struktūrizuoti interviu apklausiant socialinius darbuotojus, dirbančius su socialinès rizikos šeimomis, siekiant nustatyti profesineje veikloje patiriamas problemas. Tyrime dalyvavo 4 socialiniai darbuotojai, dirbantys su socialinès rizikos šeimomis. Tyrimo dalyvių amžius svyruoja nuo 24 metų iki 45 metų, o darbo patirtis su socialinès rizikos šeimomis svyruoja nuo pusès iki 8 metų. Užtikrinant konfidencialumą tyrimo dalyviams suteikti kodai nuo 1 TD iki 4 TD.

\section{Tyrimo rezultatai}

Socialinès rizikos šeimų skaičius, tenkantis vienam socialiniam darbuotojui (1 lentelè). Šiuo metu galiojantys teisès aktai nereglamentuoja socialinių darbuotojų, dirbančių su socialinès rizikos šeimomis, darbo krūvių. Tyrimo rezultatai rodo, kad vienam socialiniam darbuotojui skiriamas per didelis socialinès rizikos šeimų skaičius. Visi tyrimo dalyviai patvirtino, kad krūvis yra per didelis dirbant su $15-21$ socialinès rizikos šeima. Turint tiek socialinès rizikos šeimų nukenčia socialinių darbuotojų kokybiška veikla, jie jaučia mažiau pasitenkinimo savo darbu. 2 TD teigia: „Krūvis yra per didelis, kadangi nepavyksta kokybiškai teikti socialines paslaugas šeimoms." Tyrimo dalyviai nurodè, kad optimalus socialinès rizikos šeimų skaičius, tenkantis vienam socialiniam darbuotojui, turètų būti

1 lentelè. Socialinès rizikos šeimų skaičius, tenkantis vienam socialiniam darbuotojui

\begin{tabular}{|c|c|}
\hline Kategorija & Patvirtinantis teiginys \\
\hline \multirow{4}{*}{$\begin{array}{l}\text { Socialinès rizikos } \\
\text { šeimų skaičius, } \\
\text { tenkantis } \\
\text { vienam sociali- } \\
\text { niam darbuotojui }\end{array}$} & $\begin{array}{l}\text { „Dabar turiu } 17 \text { šeimų, } 9 \text { iš jų yra soci- } \\
\text { alinės rizikos šeimų apskaitoje, likusios } \\
\text { nèra apskaitoje, bet paslaugos joms taip } \\
\text { pat teikiamos.“( } 1 \text { TD) }\end{array}$ \\
\hline & $\begin{array}{l}\text { „Socialinės rizikos apskaitoje turiu } 21 \\
\text { šeimą.“ (2 TD) }\end{array}$ \\
\hline & $\begin{array}{l}\text { „Turiu } 15 \text { socialinès rizikos šeimų.“ (3 } \\
\text { TD) }\end{array}$ \\
\hline & $\begin{array}{l}\text { „Turiu } 15 \text { socialinès rizikos šeimų, su ku- } \\
\text { riomis dirbu.“( } 4 \text { TD) }\end{array}$ \\
\hline \multirow{3}{*}{$\begin{array}{l}\text { Optimalus so- } \\
\text { cialinės rizikos } \\
\text { šeimų } \\
\text { skaičius sociali- } \\
\text { nių darbuotojų } \\
\text { nuomone }\end{array}$} & $\begin{array}{l}\text { „Iki } 10 \text { šeimų, tada gali pasiskirstyti, per } \\
\text { dieną apsilankyti kokių } 2 \text { šeimų namuo- } \\
\text { se.“( } 1 \text { TD) }\end{array}$ \\
\hline & $\begin{array}{l}\text { „Optimalus skaičius būtų } 7 \text { šeimos, bet ir } \\
\text { tai, jeigu turi gerą praktiką, patirtị šioje } \\
\text { srityje.“ ( } 3 \text { TD) }\end{array}$ \\
\hline & $\begin{array}{l}\text { „Kad darbas būtų efektyvus, turètų būti } \\
\text { kokios } 6-7 \text { šeimos.“ (4 TD) }\end{array}$ \\
\hline
\end{tabular}

iki 10 šeimų. Jų nuomone, tada darbas vyktų kokybiškiau ir efektyviau, būtų galima greičiau pasiekti pokyčių šeimų gyvenime.

Socialinio darbuotojo patiriamos problemos bendraujant su socialinès rizikos šeimomis (2 lentelè). I. Dirgelienè ir A. Kiaunyte teigia, kad socialiniai darbuotojai dalyvauja specifineje veikloje - interakcijos procese, kur susiduria socialinis darbuotojas ir klientas. Santykiai gali būti dinamiški: nuo bendradarbiavimo iki konflikto [2]. Anot L. Gvaldaitès ir B. Švedaitès, socialiniai darbuotojai, dirbantys su socialinès rizikos šeimomis, nori užmegzti ryši su šeimomis ir padèti joms keistis, tačiau, kita vertus, socialiniai darbuotojai turi atlikti ir kontrolieriaus vaidmenį: surinkti visą informaciją, apklausti kaimynus, išsiaiškinti, ar vaikui saugu šeimoje, kontroliuoti. Tai vadinama „dvigubo mandato" dilema ir tai supriešina socialinị darbuotoją su klientu, sukelia šeimos narių nepasitikèjimą, nenorą bendrauti [3]. Tyrimo rezultatai atskleide, kad bendraudami su socialinès rizikos šeimomis socialiniai darbuotojai patiria tokias problemas: socialinès rizikos šeimų nariai vengia bendravimo ir susitikimų su socialiniu darbuotoju, meluoja socialiniam darbuotojui, kartais pasitaiko agresyvių klientu, kurie bendrauja pakeltu tonu, rékia. Viena tyrimo dalyve (3 TD) nurode, kad bendravimui ir tarpusavio ryšio sukūrimui didelę ịtaką daro socialinio darbuotojo amžius. 3 TD teigia, kad klientai yra nelinkę pasitikèti jau-

2 lentelè. Socialinio darbuotojo patiriamos problemos bendraujant su socialinès rizikos šeimomis

\begin{tabular}{|c|c|c|}
\hline $\begin{array}{l}\text { Katego- } \\
\text { rija }\end{array}$ & $\begin{array}{c}\text { Subkate- } \\
\text { gorija }\end{array}$ & Patvirtinantis teiginys \\
\hline \multirow{4}{*}{$\begin{array}{l}\text { Socialinio } \\
\text { darbuoto- } \\
\text { jo patiria- } \\
\text { mos pro- } \\
\text { blemos } \\
\text { bendrau- } \\
\text { jant su } \\
\text { socialinės } \\
\text { rizikos } \\
\text { šeimomis }\end{array}$} & \multirow{2}{*}{$\begin{array}{l}\text { Socialinès } \\
\text { rizikos } \\
\text { šeimų } \\
\text { priešinima- } \\
\text { sis }\end{array}$} & $\begin{array}{l}\text { „Šeimos priešinasi, nepripažįsta } \\
\text { problemų, nuolat meluoja, vengia } \\
\text { susitikti, todėl tas bendravimas } \\
\text { toks apsunkintas.“ ( } 1 \text { TD) }\end{array}$ \\
\hline & & $\begin{array}{l}\text { „Dažnai klientai sako, kad viską } \\
\text { moka, sugeba, kad jiems nereikia } \\
\text { mano pagalbos.“ (4 TD) }\end{array}$ \\
\hline & $\begin{array}{l}\text { Socialinès } \\
\text { rizikos šei- } \\
\text { mos nenori } \\
\text { bendrauti }\end{array}$ & $\begin{array}{l}\text { „Šeimos, kurios nepripažista pro- } \\
\text { blemų, atsisako bendrauti, vengia } \\
\text { bendrauti arba bendrauja pakeltu } \\
\text { tonu, rèkia. Kai klientas nepripa- } \\
\text { žista savo šeimos problemų, jas } \\
\text { neigia, nėra atviro bendravimo ir } \\
\text { tarpusavio pasitikejjimo.“ ( } 2 \text { TD) }\end{array}$ \\
\hline & $\begin{array}{l}\text { Priklauso } \\
\text { nuo socia- } \\
\text { linio } \\
\text { darbuotojo } \\
\text { amžiaus }\end{array}$ & $\begin{array}{l}\text { „Jeigu suaugusi moteris - žiūri } \\
\text { palankiai, jeigu jauna mergina - } \\
\text { sunku bendrauti, nes klientai neti- } \\
\text { ki, kad jauna socialinè darbuotoja } \\
\text { gali jiems kaip nors padèti.“ (3 } \\
\text { TD) }\end{array}$ \\
\hline
\end{tabular}


nu socialiniu darbuotoju, nes nemano, kad jaunas darbuotojas gali suprasti jų problemas ir padèti.

Socialinio darbuotojo patiriamos problemos lankymosi socialinès rizikos šeimų namuose metu (3 lentelè). L. Gvaldaitès ir B. Švedaitès teigimu, socialinio darbuotojo klientai priklauso silpniausiam, skurdžiausiam visuomenès sluoksniui - jiems ypač sunku peržengti oficialių tarnybų, kabinetų slenksčius, patiems ieškotis pagalbos. Dèl to socialiniai darbuotojai turi kuo daugiau veikti klientu aplinkoje, turi eiti pas klientus i jų natūralią aplinką ir ten veikti, o ne atvirkščiai [3]. Lankymasis socialinès rizikos šeimų namuose yra vienas iš geriausių būdų įvertinti šeimos situaciją, tačiau, pasak J. Vyšniauskytès - Rimkienès ir T. N. Liobikienès, saugumo atžvilgiu socialinių darbuotojų vizitai pas klientus į namus yra rizikingi. Dažniausiai šeimose, kuriose vartojamas alkoholis, narkotikai, smurtaujama, yra psichikos ligoniu, lankosi po vieną socialinį darbuotoją, todèl jam nèra saugu, nes gali susidurti su nenuspejamu klientų elgesiu. Taip pat kyla grèsmé užsikrèsti pavojingomis ligomis, nukentèti nuo namuose laikomų šunų [7]. Tyrimo

3 lentelè. Socialinio darbuotojo patiriamos problemos lankymosi socialinès rizikos šeimų namuose metu

\begin{tabular}{|c|c|c|}
\hline $\begin{array}{l}\text { Katego- } \\
\text { rija }\end{array}$ & $\begin{array}{l}\text { Subkatego- } \\
\text { rija }\end{array}$ & Patvirtinantis teiginys \\
\hline \multirow{5}{*}{$\begin{array}{l}\text { Socialinio } \\
\text { darbuoto- } \\
\text { jo patiria- } \\
\text { mos pro- } \\
\text { blemos } \\
\text { lankymosi } \\
\text { socialinės } \\
\text { rizikos } \\
\text { šeimų } \\
\text { namuose } \\
\text { metu }\end{array}$} & \multirow[t]{2}{*}{ Nesaugumas } & $\begin{array}{l}\text { „Visada yra rizika, kad galiu būti } \\
\text { fiziškai sužalota žmonių arba } \\
\text { šunų, galiu užsikrèsti kokia liga, } \\
\text { būti apšaukta, morališkai paže- } \\
\text { minta.“( } 1 \text { TD) }\end{array}$ \\
\hline & & $\begin{array}{l}\text { „Dažnai klientai namuose laiko } \\
\text { šunis, kurie yra palaidi ir ke- } \\
\text { lia grèsmę. Kai kurie klientai } \\
\text { įsileidę užsirakina duris ir taip } \\
\text { kyla grèsmė dèl pasišalinimo iš } \\
\text { namų." (2 TD) }\end{array}$ \\
\hline & $\begin{array}{l}\text { Nepatenkinti } \\
\text { klientai }\end{array}$ & $\begin{array}{l}\text { „Klientai labai nepatenkinti, kad } \\
\text { pas juos lankausi, nenori ben- } \\
\text { drauti, nuolat pasipiktinę klau- } \\
\text { sia: kodėl čia vaikštot, kiek laiko } \\
\text { dar vaikščiosit?“ ( } 1 \text { TD) }\end{array}$ \\
\hline & $\begin{array}{l}\text { Diskomfor- } \\
\text { tas }\end{array}$ & $\begin{array}{l}\text { „Kai pradèjau dirbti su sociali- } \\
\text { nės rizikos šeimomis, pirmajị } \\
\text { mėnesi buvo baisoka. Jaučiau } \\
\text { diskomfortą, kad einu i tą pur- } \\
\text { vą, galiu kokią ligą parsinešti.“ } \\
\text { (3 TD) }\end{array}$ \\
\hline & $\begin{array}{l}\text { Klientų nu- } \\
\text { sistatymas } \\
\text { prieš sociali- } \\
\text { nius darbuo- } \\
\text { tojus }\end{array}$ & $\begin{array}{l}\text { "Jie supranta, kad ateina val- } \\
\text { džios atstovas, todèl būna prie- } \\
\text { šiškai nusiteikę.“ (4 TD) }\end{array}$ \\
\hline
\end{tabular}

rezultatai atskleidè, kad lankymosi socialinės rizikos šeimų namuose metu socialiniai darbuotojai patiria tokias problemas: nesaugumas, socialinès rizikos šeimų nariai nepatenkinti, kad socialinis darbuotojas lankosi jų namuose, todèl būna priešiškai nusiteikę darbuotojo atžvilgiu. Pasak 3 TD, jai tik pirmaji mėnesį, kai pradejo dirbti su socialinès rizikos šeimomis, buvo baisu lankytis šeimų namuose, dabar ji jaučiasi nesaugiai tik dèl išorinès aplinkos. Tyrime dalyvavęs socialinis darbuotojas (3 TD) teigia: „Labiausiai aš jaučiu nesaugumą dèl aplinkos. Būti pas klientus namuose aš nebijau, tačiau turiu klientų, kurie gyvena bendrabučiuose ir man nerimą kelia ne apsilankymas pas konkrečią šeimą namuose, bet èjimas ị tą bendrabutị, kur pilna alkoholikų, narkomanų.

Socialinio darbuotojo patiriamos problemos teikiant socialines paslaugas socialinės rizikos šeimoms (4 lentelè). Socialinès paslaugos socialinès rizikos šeimoms teikiamos padedant ugdyti suaugusių šeimos narių socialinius igūdžius ir motyvaciją kurti saugią, sveiką, darnią aplinką savo namuose, šeimoje, palaikyti socialinius ryšius su visuomene ir užtikrinti šeimoje augančių vaikų visapusị vystymąsi ir ugdymą. Taip pat siekiama, kad socialinès rizikos šeimos stiprintu gebejimus ir galimybes savarankiškai spręsti savo socialines problemas, ịveiktų socialinę

4 lentelè. Socialinio darbuotojo patiriamos problemos teikiant socialines paslaugas socialinès rizikos šeimoms

\begin{tabular}{|c|c|c|}
\hline $\begin{array}{l}\text { Katego- } \\
\text { rija }\end{array}$ & $\begin{array}{l}\text { Subka- } \\
\text { tegorija }\end{array}$ & Patvirtinantis teiginys \\
\hline \multirow{6}{*}{$\begin{array}{l}\text { Socialinio } \\
\text { darbuoto- } \\
\text { jo patiria- } \\
\text { mos pro- } \\
\text { blemos } \\
\text { teikiant } \\
\text { socialines } \\
\text { paslaugas } \\
\text { socialinès } \\
\text { rizikos } \\
\text { šeimoms }\end{array}$} & \multirow{2}{*}{$\begin{array}{l}\text { Soci- } \\
\text { alinės } \\
\text { rizikos } \\
\text { šeimų } \\
\text { pasyvu- } \\
\text { mas }\end{array}$} & $\begin{array}{l}\text { „Buriu jiems, kad reikia pakeisti } \\
\text { aplinką, susipažinti su kitais, bet jie } \\
\text { pasyviai ì tai žiūri, nenori keisti nu- } \\
\text { sistovėjusio gyvenimo būdo. Jie sėdi } \\
\text { savo kiaute ir jiems atrodo, kad vis- } \\
\text { kas gerai.“( } 3 \text { TD) }\end{array}$ \\
\hline & & $\begin{array}{l}\text { „Didžiausia problema, kad klientai } \\
\text { nepripažista šeimoje esančių proble- } \\
\text { mų, yra nemotyvuoti jas spręsti, yra } \\
\text { igiję išmoktą bejègiškumą.“ (2 TD) }\end{array}$ \\
\hline & \multirow{2}{*}{$\begin{array}{l}\text { Susi- } \\
\text { tarimų } \\
\text { nevyk- } \\
\text { dymas }\end{array}$} & $\begin{array}{l}\text { „Šeimos meluoja, nevykdo bendrų } \\
\text { susitarimų arba juos atidèlioja vyk- } \\
\text { dyti.“ ( } 2 \text { TD) }\end{array}$ \\
\hline & & $\begin{array}{l}\text { „Sunku sudaryti sutartị su klientais ir } \\
\text { jiems jos laikytis. Jie dažnai nesilaiko } \\
\text { duoto žodžio.“ (4 TD) }\end{array}$ \\
\hline & $\begin{array}{l}\text { Atme- } \\
\text { timo } \\
\text { reakcija }\end{array}$ & $\begin{array}{l}\text { „Pasakai, kad reikia dirbti, duodi } \\
\text { surastus darbo skelbimus, o klientas } \\
\text { suranda milijoną priežasčių, kodèl } \\
\text { negali dirbti.“( } 3 \text { TD) }\end{array}$ \\
\hline & $\begin{array}{l}\text { Išteklių } \\
\text { stoka }\end{array}$ & $\begin{array}{l}\text { „Trūksta fondų, kurie galètų padèti.“ } \\
\text { (1 TD) }\end{array}$ \\
\hline
\end{tabular}


atskirti [5]. Tyrimo rezultatai atskleidè, kad teikdami socialines paslaugas socialinès rizikos šeimoms socialiniai darbuotojai patiria tokias problemas: socialinès rizikos šeimų narių pasyvumas priimant paslaugas, nenoras keisti nusistovejusio gyvenimo būdo, įsipareigojimų nevykdymas, melavimas. Viena tyrimo dalyvė nurodè, kad teikiant socialines paslaugas trūksta fondų, kurie galètų padèti. Tyrimo dalyvis (1 TD) teigia: „Dažnai tokioms šeimoms reikia materialinès pagalbos daiktais (lovos, spintelès, drabužiai ir pan.), bet ne visada pavyksta jų gauti.“

Socialinio darbuotojo patiriamos problemos bendradarbiaujant su kitomis institucijomis ir socialiniais partneriais (5 lentelè). Socialinio darbo profesija yra labai svarbi siekiant, kad visuomenè sveikai funkcionuotų, tačiau socialiniai darbuotojai dažnai susiduria su vis dar neigiamu visuomenès požiūriu ị šią profesiją. Socialiniai darbuotojai ne kartą yra pajutę savo, kaip socialinio darbuotojo profesijos atstovo, pažeminimą, veiklos nuvertinimą. Ypač tai pasireiškia ịvairių dalykinių susitikimų, aptarimų metu. Socialiniai darbuotojai dažnai jaučiasi neišgirsti, nesuprasti, ignoruojama jų nuomoné, jų darbas laikomas ne tokiu svarbiu kaip kitų sričių darbuotojų $[6,8]$. Tyrimo rezultatai atskleide, kad bendradarbiaudami su kitomis institucijomis ir socialiniais partneriais socialiniai darbuotojai patiria tokias problemas: nuvertinimas, kitos institucijos nelinkusios

5 lentelė. Socialinio darbuotojo patiriamos problemos bendradarbiaujant su kitomis institucijomis, socialiniais partneriais

\begin{tabular}{|c|c|c|}
\hline $\begin{array}{l}\text { Katego- } \\
\text { rija }\end{array}$ & $\begin{array}{c}\text { Subkate- } \\
\text { gorija }\end{array}$ & Patvirtinantis teiginys \\
\hline \multirow{6}{*}{$\begin{array}{l}\text { Socialinio } \\
\text { darbuotojo } \\
\text { patiriamos } \\
\text { problemos } \\
\text { bendradar- } \\
\text { biaujant } \\
\text { su kitomis } \\
\text { institucijo- } \\
\text { mis, so- } \\
\text { cialiniais } \\
\text { partneriais }\end{array}$} & $\begin{array}{l}\text { Nuverti- } \\
\text { nimas }\end{array}$ & $\begin{array}{l}\text { „Nuvertina labai mus. Socialinio } \\
\text { darbuotojo specialybè negerbia- } \\
\text { ma.“( } 1 \text { TD) }\end{array}$ \\
\hline & \multirow{3}{*}{$\begin{array}{l}\text { Kitos } \\
\text { institu- } \\
\text { cijos ne- } \\
\text { linkusios } \\
\text { bendra- } \\
\text { darbiauti }\end{array}$} & $\begin{array}{l}\text { „Kitos institucijos isitikinusios, } \\
\text { kad socialinis darbuotojas yra vis- } \\
\text { kas viename ir turi viską padaryti.“ } \\
(2 \text { TD) }\end{array}$ \\
\hline & & $\begin{array}{l}\text { „Toks jausmas, kad kiekviena ins- } \\
\text { titucija dirba atskirai, kiekvienas } \\
\text { už save, nėra glaudaus bendradar- } \\
\text { biavimo.“ ( } 3 \text { TD) }\end{array}$ \\
\hline & & $\begin{array}{l}\text { „Pagrindinè problema, kad nėra } \\
\text { bendrų nuostatų, trūksta susitari- } \\
\text { mų, neinformuoja laiku.“ (1 TD) }\end{array}$ \\
\hline & $\begin{array}{l}\text { Netvirtas } \\
\text { ryšys }\end{array}$ & $\begin{array}{l}\text { „Norètųsi, kad tas ryšys būtų daug } \\
\text { tvirtesnis, kad labiau mumis pasiti- } \\
\text { kètų.“ (4 TD) }\end{array}$ \\
\hline & $\begin{array}{l}\text { Konfiden- } \\
\text { cialumo } \\
\text { nesilaiky- } \\
\text { mas }\end{array}$ & $\begin{array}{l}\text { „Konfidencialumo nesilaiko svei- } \\
\text { katos įstaigos dažnai.“ (4 TD) }\end{array}$ \\
\hline
\end{tabular}

bendradarbiauti, neinformuoja laiku, nesilaiko konfidencialumo principo. Tyrimo dalyvis (4 TD) teigia: „Socialinis darbuotojas yra lyg paskutine institucija ir dažnai iš kitų institucijų dar tenka išgirsti: ,ir dar jūs ginat tuos savo klientus", bet kai įsigilini ị situacijas šeimose, kartais kitaip ir neįmanoma pasielgti.“

\section{Išvados}

1. Socialinès rizikos šeima - tai šeima, kurioje narių bendradarbiavimas ir emocinis bendravimas yra sutrikę ir kurios neigiama aplinka neskatina sveiko ir produktyvaus asmenybès augimo ir vystymosi. Socialinès rizikos šeimoms būdingas negebejjimas savarankiškai spręsti savo problemų, šeimos funkcijų sutrikimas, jos narių poreikių nepakankamas tenkinimas. Socialinès rizikos šeimų formavimosi priežastys yra labai ịvairios, tačiau pagrindinès yra socialinè atskirtis, alkoholio vartojimas, skurdas ir nedarbas.

2. Darbas su socialinès rizikos šeimomis yra įvairiapusiškai sudètingas, reikalaujantis didžiulès emocinès investicijos. Socialiniai darbuotojai nuolat susiduria su problemomis, kurios kelia grèsmę ne tik psichologiniam, bet ir fiziniam jų saugumui.

3. Atlikto tyrimo rezultatai atskleidè, kad socialiniai darbuotojai, dirbantys su socialinès rizikos šeimomis, dažnai susiduria su ịvairiomis problemomis. Socialiniams darbuotojams priskiriamas per didelis socialinès rizikos šeimų skaičius. Turint daug šeimų nukenčia socialinių darbuotojų kokybiška veikla, jie jaučia mažiau pasitenkinimo savo darbu. Socialiniai darbuotojai susiduria su socialinès rizikos šeimų problemų neigimu, motyvacijos stoka ir nenoru keisti nusistovèjusi gyvenimo būdą, priešišku nusiteikimu socialinio darbuotojo atžvilgiu. Tyrime dalyvavę darbuotojai pažymi tarpinstitucinio bendradarbiavimo stoką sprendžiant rizikos šeimų problemas.

\section{Literatūra}

1. Darbo su socialinès rizikos šeimomis metodinès rekomendacijos. Vilnius, 2003 m. gruodžio 17 d. Nr. A1-207.

2. Dirgèlienè I., Kiaunytė A. Supervizija Lietuvos socialinio darbo kontekste. Vilnius, 2005.

3. Gvaldaitė L., Švedaite B. Socialinio darbo metodai. Vilnius, 2005.

4. Johnson L. C. Socialinio darbo praktika. Vilnius, 2001.

5. LR Socialinių paslaugų ịstatymas. Vilnius, $2006 \mathrm{~m}$. sausio 19 d. Nr. X-493.

6. Mąstyti, veikti, būti. Socialinis darbas organizacijoje / Lies Gualthérie van Weezel, K. Alkimavičius, G. Aukščiūnienè ir kt. Lietuvos socialinių darbuotojų asociacija, 2010.

7. Vyšniauskytè-Rimkienè J., Liobikienè T. N. Gebëjimai socia- 
linio darbo praktikoje. Kaunas, 2010.

8. Hoffler EF, Clark EJ. Social Work Matters: The Power of Linking Policy and Practice. Washington, 2012.

9. Repetti RL, Taylor SE, Seeman TE. Risky Families: Family Social Environments and the Mental and Physical Health of Offspring. University of California, Los Angeles, 2002. http:// repettilab.psych.ucla.edu/repetti $\% 20$ taylor $\% 20$ seeman $\% 20$ 2002.pdf [žiūrèta 2015-04-16].

\section{THE ISSUES OF SOCIAL WORKER DEALING WITH SOCIAL RISK FAMILIES}

E. Stasiūnaitienė, S. Mažeikaitè

Key words: social worker, problem, social risk family.

Summary

Social work with social risk families has a variety of difficulties. Social worker often encounters issues that jeopardise not only his psychological, but also physical safety, while trying to help social risk families to cope with their problems. The analysis of the research results shown that the research participants most often encounter problems when they are communicating with social risk families and when they are providing social services to those families. They experience these issues because of those families' negative attitude towards social workers, their avoiding to communicate, lack of motivation and passiveness towards changing. The research shows that most of the participants feel anxious about visiting social risk families, because of the danger to their physical safety. The research participants also emphasized that they feel lack of closer cooperation within the institutions.

Correspondence to: egle.stasiunaitiene@go.kauko.lt

Gauta 2015-09-25

\section{KVIEČIAME PRENUMERUOTI “SVEIKATOS MOKSLŲ” ŽURNALĄ 2016 METAIS!}

Žurnalas "Sveikatos mokslai" (Index Copernicus, EBSCO host (Academic Search Complete), Gale (Academic OneFile), ProQuest (Ulrich's, Summon), Australia (ERA) 2012 Journal List (ERA ID 34962) skirtas visų specialybiu gydytojams, slaugytojams ir kitiems specialistams, spausdina mokslinius straipsnius lietuvių, anglų kalbomis. Reikalavimai straipsniams atitinka mokslo leidiniams keliamus reikalavimus.

Žurnalas kioskuose neparduodamas.

Žurnalą, kuris leidžiamas kartą per du mẻnesius, galima užsiprenumeruoti visuose Lietuvos pašto skyriuose, taip pat internetu: www.post.lt

Prenumeratos kaina nesikeičia: visiems metams - 34,75 EUR (120 Lt), šešiems mẻnesiams 17,37 EUR (60 Lt), keturiems mėnesiams - 11,58 EUR (40 Lt), dviem mėnesiams - 5,79 EUR (20 Lt).

Prenumeratos kodas: 5348.

Žurnalo autoriams straipsnių spausdinimas mokamas. 